\title{
ЭТНОГРАФИЯ
}

\section{М.М. Магомедханов}

\section{ОСОБЕННОСТИ ЭТНОЯЗЫКОВЫХ ПРОЦЕССОВ В ЮЖНОМ ДАГЕСТАНЕ}

Южный Дагестан по сложности этнической структуры, представленной рутулами, цахурами, агулами, лезгинами, табасаранцами, горскими евреями, азербайджанцами, терекемейцами и отчасти кумыками и даргинцами, вполне сопоставим с Западным Дагестаном, где сосредоточена половина всей этнической номенклатуры Дагестана. Но даже на фоне мозаичной конфигурации этноязыковой карты Дагестана г. Дербент с примыкающими к нему территориями занимает особое положение. Эта часть Прикаспийской области уже с сасанидского периода и вплоть до наших дней продолжает оставаться зоной в высшей степени интенсивных этноязыковых контактов (Кудрявиев А.А., 1981; Гаджиев М.С., 2000).

Как известно из истории, шах Хосров I Ануширван (531-579 гг.) построил в Дербенте уникальные по своей архитектуре оборонительные сооружения, закрывавшие узкий дербентский проход от вторжений воинственных кочевников с севера и поселил там стражников из разных областей Ирана. Есть предположение, что к сасанидскому периоду относится и появление в районе Дербента ираноязычных горских евреев. Письменные источники VIII-XII вв. среди жителей Дербента и его окрестностей упоминают армян, хазар, табасаранцев, а также арабов, которые населяли близлежащие к Дербенту с. Арабляр, Гимейди, Дарваг, Ерси, Кемах. К концу XIX в. арабы ассимилировались с азербайджанцами и табасаранцами, хотя и продолжали помнить о своем арабском происхождении (Артамонов М.И., 1962; Минорский В.Ф., 1963; Шихсаидов А.Р., 1975; Гадло А.В., 1979).

Вопрос о языковой ситуации в средневековом Дербенте заслуживает отдельного рассмотрения. Здесь же отметим, что, по меньшей мере, с VIII в. н. э. Дербент находился в тесных политических, экономических и культурных связях с Ширваном и формирование этнического состава Ширвана и Дербента происходило, по существу, в едином русле (Буниятов 3.М., 1965; Шихсаидов А.P., 1975). Вероятно, уже с середины XI в. наибольшее распространение здесь получил язык тюркского корня, так как с этого времени начинается господство тюрков-сельджуков, сыгравших определяющую роль в формировании азербайджанского этноса. Можно предположить, что в период монголо-татарской экспансии (XIII-XIV вв.) и до начала XVI в. этнический состав населения Дербента и близлежащих районов не подвергался значительным изменениям. В начале XVI в. город попал под власть Сефевидов, а в конце XVI в. его захватили турки-османы. В начале XVII в. Дербент вновь перешел к Сефевидам, а со второй половины того же столетия и до начала XVIII в. им правили персидские наместники.

Сефевиды вели активную переселенческую политику. Сотни семей (в основном тюркоязычных) из Тебриза и других северных провинций Персии обрели в Дербенте новое место жительства (Козубский Е.И., 1906; Бакиханов А.-К. А., 1926). В тот же период Русское государство начало реализовывать свои политические и экономические интересы в Прикаспийской области. В Дербент стали прибывать русские посольства и купцы (Гаджиев В.Г., 1965. С. 65-80).

По сообщению И.Г.Гербера (XVIII в.) среди горожан «...много купецких людей из персиянов, армянов, грузинцев и индийцев» (История, география и этнография Дагестана, 1958. С.86) (Под «персиянами» здесь имеется в виду тюркоязычное население города. - Авт.). 
После того как в августе 1722 г. Петр I взял Дербент без боя, им был оставлен в городе русский гарнизон. По его же поощрению для активизации торговли в городе поселялись армяне. С окончательным присоединением Дербента к России (1806 г.) русское воинское и гражданское население жило в цитадели города Нарын-Кала и во вновь построенных кварталах (магалах) в приморской части - Дубарах. Центральные кварталы города занимали горские евреи и армяне. В остальных девяти кварталах проживали азербайджанцы, а окраины города занимали представители народов Южного Дагестана.

Хотя за два истекших века этническая структура населения Дербента и претерпела изменения, но не столь кардинальные, как в других городах Дагестана. Сегодня этнический облик города определяют лезгины, азербайджанцы, табасаранцы и горские евреи, численность которых в связи с эмиграцией в Израиль уменьшается с каждым днем.

Ни в Дербенте, ни в других местах проживания Дагестана горско-еврейское население края не испытывало языкового барьера. Значительная их часть жила анклавами по соседству с лезгинами, азербайджанцами, татами-мусульманами, табасаранцами, кумыками, кайтагцами.

Торговля - один из самых эффективных факторов межэтнического общения. География торговых связей горских евреев охватывала отдаленные уголки Дагестана, север Азербайджана и юг России. Этим во многом объясняется факт практического отсутствия среди взрослого мужского населения горских евреев лиц, не владевших азербайджанским (до недавнего времени основное средство межэтнического общения в данном регионе) или кумыкским, а с последней четверти XIX в. и русским языками. Здесь же отметим, что горско-еврейский (по официальной номинации - татский) язык отнесен к 14-ти «конституционным» языкам Дагестана, т.е. к языкам, на которых издаются газеты, книги, ведутся радиопередачи, ставятся спектакли и т.д. В советское время на «расцвет и сближение социалистических наций и национальных культур» выделялись бюджетные средства. Такая политика, наряду с обеспечением представительства в партийных и государственных органах, создавала у горских евреев ощущение этнического равноправия. «Татская социалистическая культура», как и другие национальные культуры Дагестана, была дотационной. Сегодня масштабы потребления этой культуры, ограниченные малым «демографическим ресурсом» горских евреев, стали в связи с массовой эмиграцией в Израиль ничтожными.

Дербент исторически являлся своего рода «культурным спутником» Баку. Сохранявшиеся вплоть до распада СССР тесные связи Дагестана и Азербайджана способствовали тому, что дагестанские азербайджанцы, лезгины, цахуры, рутулы, горские евреи, т.е. народы, имевшие относительно крупные диаспоры в административных границах Азербайджана, стали ориентироваться на азербайджанский столичный образ жизни. Возможно, в этом и состоит одна из причин того, что в отличие от других дагестанских городов Дербент и сегодня продолжает сохранять в целом азербайджанскую языковую и культурно-бытовую атмосферу. Поскольку основные функции языка межэтнического общения в Дербенте и прилегающих к нему районах, равно как и во всем Южном Дагестане, выполнял азербайджанский язык, дагестанские азербайджанцы вплоть до конца XIX в., т.е. до распространения среди них русского языка, владели в основном только своим, т.е. азербайджанским языком.

В дореволюционном Дагестане процессы языковой ассимиляции носили эпизодический характер и были связаны главным образом с миграциями отдельных семей в иноэтническую среду. Переселение из одного населенного пункта в другой означало безоговорочное принятие порядков, образа жизни, освоение языка (диалекта) того сельского общества, в который вселялись пришельцы. Но даже после полной «натурализации» и ассимиляции в новой среде потомки выходцев из «других» мест или этнических групп на протяжении жизни пяти и более поколений продолжали пом- 
нить о родовом селении и происхождении своих предков.

В XVIII-XIX вв. этноязыковой ассимиляции подвергались в основном отдельные группы переселенцев. Уникальным в этноязыковой истории Дагестана можно считать факт перехода с. Алак с табасаранского на азербайджанский язык только лишь по той причине, что бекская семья в данном селении говорила на азербайджанском языке, т.е. на языке по тем временам более престижном (Алимова Б.М., 1992. С. $18)$.

Как отмечал в 1876 г. Г. Бекер, «тюрко-азербайджанское наречие произвело ощутимое влияние на некоторые горские языки, а табасаранцы, живущие поблизости к Дербенту, забывают все более родную речь» (Поездка Г. Бекера по Южному Дагестану, 1876. С. 34).

Относительная компактность расселения азербайджанцев в Дербенте и окрестных к нему селах, наличие торгово-экономических, культурных и родственных связей с Азербайджаном, исторически сложившаяся ориентация народов Южного Дагестана на культурно-поведенческий стереотип населения Баку и других городских центров Азербайджана - все это обусловило широкое распространение на юге Дагестана азербайджанского языка и культуры.

Владение двумя и более языками еще лет 20 тому назад воспринималось дагестанцами как обычное явление. Роль основных языков межэтнического общения выполняли: а) кумыкский (в Северном и Нагорном Дагестане); б) азербайджанский и отчасти лезгинский (в Южном Дагестане); в) аварский (в Западном Дагестане); г) лакский (в Центральном Дагестане).

Исторические параллели роли русского языка в Дагестане с аналогичной ролью тюркского или арабского языков приводят к мысли о том, что распространенность последних не сопровождалась сколько-нибудь существенными процессами языковой ассимиляции. Так, задолго до XIX в. наметившиеся тенденции расширения социальных функций тюркского (азербайджанского) языка на территории Южного Дагестана затронули главным образом сферу «культурного потребления», но мало повлияли на речевое поведение лезгин, цахуров, рутулов, агулов в быту.

Знание лезгинского языка было нередким явлением среди рутулов, цахуров, агулов, табасаранцев. Однако в отличие от андо-цезких народов и арчинцев, для которых продуктивное использование аварского языка и аварской письменности является объективным основанием их культурной идентичности с аварцами, социальнокоммуникативные функции лезгинского языка среди народов Южного Дагестана были ограничены сферой бытового межэтнического общения. Показателен в этой связи пример почти полного отсутствия сочинений на лезгинском языке, созданных табасаранцами, рутульцами, цахурами, агулами. Более того, по сложившейся традиции доминирующие позиции в культурной жизни лезгин принадлежали тюркскому (азербайджанскому) языку и тюркской письменности. Как отмечает Ф. Вагабова: «Языку, известному в горах как тюркский принадлежат здесь (в Южном Дагестане. Авт.) позиции едва ли не равные, а в литературе даже и больше, чем языкам местным» (Вагабова Ф., 1970. С. 77).

За редкими исключениями, обусловленными чересполосным расселением с азербайджанцами (табасаранцы, кубинские лезгины), ведущие позиции в общественном быту, не говоря уже о семейной сфере, все же оставались за родными языками. К тому же агульцы, которые граничат и традиционно поддерживают экономические и куначеские отношения с даргинцами (Буркун-Дарго), лакцами, кайтагцами и табасаранцами, находились в отличие от остальных народов Южного Дагестана в иной этноконтактной ситуации и в целом оставались за пределами интенсивного влияния азербайджаноязычной культурной среды. По свидетельству Е.М.Шиллинга, лезгинским языком владели агульцы, села которых располагались по соседству с лезгинами, тогда как многие агульцы, жившие рядом с даргинцами, кайтагцами, табасаранцами, лакцами знали языки этих народов (Шиллинг E.M., 1996. С. 52). 
В последней четверти XIX в., особенно в начале XX в., с вовлечением Дагестана в общероссийскую систему капиталистических отношений, оживлением экономики, торговли, отходничества, миграционными процессами и формированием городского населения в этноязыковой жизни Дагестана происходили существенные изменения. Выразились они и в возрождении дагестанской литературы (Гамзатов Г.Г., 2000), и в расширении социальных функций русского языка.

Воплощение в жизнь ленинских идей о национально-языковой и культурной политике - это целая эпоха в истории народов СССР и России. Специфичен в этом отношении и дагестанский опыт (Каймаразов Г.Ш., 1971).

В советский период национально-языковое строительство рассматривалось как составная часть культурной революции. Историческое значение для развития культурной жизни многоязычного Дагестана имели решения Х съезда РКП (б) (март 1921 г.) о необходимости развивать «прессу, школу, театр, клубное дело и вообще культурно-просветительные учреждения на родном языке; поставить и развить широкую сеть курсов и школ, как общеобразовательного, так и профессиональнотехнического характера на родном языке (в первую голову для киргиз, башкир, туркмен, узбеков, таджиков, азербайджанцев, татар, дагестанцев)» (КПСС в резолюциях, Ч. І. С. 559).

Как можно судить по развернувшимся в Дагестане в 1927-28 гг. жарким дискуссиям вокруг вопросов о языках, для принятия соответствующих дагестанской языковой действительности практических решений одних только партийных директив или одухотворенности большевиков идеями культурной революции оказалось недостаточно.

В полемике участвовали не только партийные и государственные деятели, интеллигенция. Многочисленные собрания сельских обществ, трудовых коллективов городов и районов выносили постановления о том, на каких языках вести обучение в учебных заведениях, развивать отношения с центром, строить партийную, культурную, экономическую работу. В основе обнаружившихся в ходе этой дискуссии противоположных позиций лежал вопрос о роли тюркского, родных и русского языков в Дагестане. Как известно, за введение в Дагестане тюркского языка в качестве единого государственного языка выступали Н. Самурский, Дж. Коркмасов и др. Некоторые придерживались того мнения, что от освоения тюркского языка есть только польза, но при этом настаивали и на развитии родных языков. Следует подчеркнуть, что в понимании роли русского языка в Дагестане было продемонстрировано полное единодушие.

Для характеристики содержания и атмосферы дискуссии тех лет приведем некоторые выдержки из газеты «Красный Дагестан». Вот одна из них: «Можно ли думать, что курс на развитие родных языков отбросит дагестанские народы назад (в культурном отношении)?», - спрашивает т. Минеев. «Этого думать нельзя», - отвечает он. «Не только можно, но и нужно так думать», - ответит мало-мальски разбирающийся товарищ», - заключает автор цитируемой статьи В. Тарбеев и приводит следующий аргумент: «Во что иное обратятся Вседагестанские съезды, высшие органы страны, как не в собрания ...совершенно не понимающих друг друга людей». На предложение А. Минеева «ликвидировать тюркские педтехникумы, заменив такими или такой организацией, которая готовила бы преподавателей на родных языках» и высказывание некоего Караева о том, что по вине Дагнаркомпроса «тюркизация вылилась в османизацию», В. Тарбеев ответил так: «В буйнакском педтехникуме на 1.-Х. 1927 г. было 51 кумык, 34 аварца, 22 лака, 22 лезгина, 12 даргинцев и т.д. Обучение с ними ведется на тюркском языке. Будут ли окончившие в состоянии преподавать на родных языках? Будут. Ибо положительные знания могут быть получены на любом языке» (Так - в оригинале. - Авт.).

Причины выдвижения тюркского языка на лидирующие позиции в Дагестане В. Тарбеев обосновывал следующими аргументами: 
«1) Тюркский язык распространен в южном Дагестане, особенно потому, что лезгины не имеют своей письменности, да и вообще южный Дагестан тяготеет к Азербайджану.

2) На севере большинство населения кумыки - народ тюрко-татарского племени. Язык тюркский им, безусловно, близок.

3) Горные районы не могут обойтись без плоскости. Необходимость бывать на плоскости, соприкасаясь с населением, говорящим на тюркско-татарских языках, неизбежно приводит к постепенному усвоению ими тюркско-татарских языков (поэтому многие аварцы знают кумыкский язык).

4) Нельзя отрицать пока значение религии. Тюркский язык ближе всем народам Дагестана уже по одному тому, что он язык мусульманский» (Тарбеев B. , 1928 ).

Раскритикованный А.Минеев отреагировал на эту публикацию такими словами: «Вот тут-то высовываются шовинистические уши, а не «язык мусульманский»... Действительно, «язык мой -враг мой». Эта аргументация - медвежья услуга тюркскому языку» (Минеев А., 1928).

Не менее эффектно отреагировал на предложение обучать детей в школе на родных языках и один из участников дискуссии А. Гаджиев: «В настоящее время, писал он, идет процесс тюркизации лезгинского языка, и если даже культурные силы в Дагестане не будут помогать этому естественному стремлению языка, тюркизация языка завершится, так или иначе. Пока школы с неграмотными учителями будут ждать решения вопроса о языке, население гор будет преспокойно оставаться в темноте и невежестве. Нам нужно, - призывал он, срочно направить все усилия на борьбу с крайней некультурностью дагестанской бедноты и для этого воспользоваться готовым языком и готовой литературой, а также подготовленным персоналом педагогов близких нам наций. Мы считаем неверным попытки сторонников национальных языков пятиться дальше от культуры, создавая для тридцати национальностей свои языки... Говорить о колонизаторской роли культурного языка не приходится, так как само население расстанется со своим языком, ибо оно уже давно чувствует всю тяжесть такого родного языка. Обширная сеть школ (не таких, какие существуют у нас с малограмотными учителями) на тюркском или на русском языке, смотря по желанию населения, - вот что необходимо нам сейчас. Лет через 10-15 государственный язык придет сам собой, он будет или русский, или тюркский, или и тот и другой вместе» (Гаджиев А., 1928).

Дискуссии о возведении тюркского языка в ранг государственного были окончательно закрыты состоявшимся в 1938 г. пленумом Дагестанского обкома ВКП (б).

Мотивация выдвижения тюркского языка в статус государственного состояла, вероятнее всего, в идее сплочения народов Дагестана на основе единого языка, а не в инкриминированном в 1937-1938 гг. Н. Самурскому, Д. Коркмасову и др. пантюркизме или «подрывной деятельности» в пользу буржуазных националистов и мифических разведок. К тому же позиция Н. Самурского в этом вопросе основывалась на объективном анализе языковой ситуации в Дагестане, правда, только в южной его части. В этой связи небезынтересно отметить, что первые советские национальные газеты для лезгин, табасаранцев, других народов Южного Дагестана и, разумеется, азербайджанцев, издавались на тюркском языке. Таковой была газета «Шура Дагъистан» («Коммунистический Дагестан»), которую с 1920 по 1922 гг. издавали в г. Темир-Хан-Шуре. С 1922 по 1932 г. эта газета печаталась в г. Дербенте под названием «Дагъистан фукъараси» («Дагестанская беднота»).

В с. Ахты с 1923 по 1925 гг. на азербайджанском языке выходила газета «Самур фукъараси» («Самурская беднота»). С 1928 г. в г. Махачкале, а с 1932 г. в с. Ахты на лезгинском языке издавалась азета «Цийи дуьнья» («Новый мир»). В 1933 г. в Курахском районе был организован выпуск газеты «Дагъдин булахъ» («Горный родник») на лезгинском языке. В 1938 г. в Докузпаринском районе стала выходить другая лезгинская газета «Социализмдин рехъ» («Путь социализма»).

Газету на табасаранском языке «Уьру Табасаран» («Красный Табасаран») впер- 
вые начали издавать в 1932 г. В последующем она, как и многие издававшиеся в Дагестане газеты, неоднократно переименовывалась (с 1938 г. - «Колхоздин уьмур» («Колхозная жизнь»), с 1970 г. - «Табасарандин нурар» («Табасаранские Зори»).

Рутульская районная газета «Гызыл чобан» («Красный чабан») с 1932 по 1965 г. тоже выходила на азербайджанском языке. С 1965 г. эта газета переименована в «Животновод» и издается на русском языке.

Социальные позиции тюркского (азербайджанского) языка были в Южном Дагестане столь сильны, что в первые годы советской власти вопрос о преподавании родных языков для детей лезгин, аварцев, цахуров, рутулов, компактно проживавших в Кусарском, Хачмазском, Кубинском, Закатальском, Кахском, Белоканском, Нухинском районах Азербайджанской ССР, не ставился вообще. Впрочем, правовой статус родных языков этнических дагестанцев в Азербайджане, равно как и в Грузии, до сих пор не определен, а попытки ввести преподавание этих языков в школах встречают упорное сопротивление властей. Это обстоятельство негативно отражается на сохранении этнокультурной идентичности дагестанской диаспоры, особенно цахуров, примерно из 20 тыс. населения которых две трети являются гражданами Азербайджана. К тому же в Дагестане вплоть до 1952 г. бучение в цахурских школах велось на азербайджанском языке. В начале 30-х гг. был составлен цахурский алфавит на латинской основе, но работа над созданием письменности на этом языке продолжается.

Как пишет Г.М. Мусаев, социально-экономическое неблагополучие рутулов и цахуров в районах их традиционного расселения и обусловленная этим миграция в города республики, в Магарамкентский, Бабаюртовский районы, Краснодарский край, в Азербайджан «привели к тому, что рутулы и цахуры превратились в этнические группы, а через 20-30 лет растворятся среди многочисленных этносов». По его мнению, такой процесс произошел с рутулами, переселившимися в Магарамкентский район и живущими в Азербайджане, и «если этот процесс не остановить, то рутулы и цахуры утратят свой язык, свою традиционную культуру... перестанут существовать как этносы» (Мусаев Г.М., 1997. С. 52).

Этноязыковая ситуация в районах расселения табасаранцев (Табасаранский, Хивский, Дербенский районы, города Дербент, Дагестанские Огни и ряд прилегающих к ним селений) характеризуется наличием традиционно сложившихся и вновь возникших в связи с миграционными процессами этноконтактных зон, главным образом с азербайджанским и лезгинским населением. В Табасаранском районе собственно азербайджанскими являются с. Марага, Хилипенджик, Цанак, Арак, Ерси, Дарваг, Зиль. В райцентре Табасарана с. Хучни насчитывается примерно 600 хозяйств, половина из которых - азербайджанские, а другая половина - табасаранские. Этнически смешанными (азербайджано-табасаранскими) являются также с. Аркит и Хурвек.

Наблюдения за речевым поведением населения Табасаранского района показывают, что выбор языка общения зависит как от этнической принадлежности субъектов общения, так и от места общения. Дома, в кругу семьи и родственников общение происходит преимущественно на родном (табасаранском или азербайджанском) языке. В райцентре (с. Хучни) дети говорят между собой преимущественно на русском языке, а собрания трудовых коллективов ведутся главным образом на азербайджанском языке. Если азербайджанец оказывается в табасаранском селении, то с ним обычно говорят на азербайджанском языке и, наоборот, в азербайджанском селении с табасаранцем стараются говорить на табасаранском языке. И в этом нельзя не видеть проявление замечательного гостеприимства и этической культуры жителей Табасарана.

Русским языком в той или иной степени владеет практически все населения Табасаранского района. Как уже отмечалось, для табасаранцев знание азербайджанского языка традиционно. Однако в современных условиях прослеживается тенденция угасания данной формы билингвизма и упрочение социально-коммуникативных 
функций табасаранского языка. По нашим сведениям, сегодня в Табасаранском районе среди взрослого населения табасаранцев в возрасте от 50 и старше азербайджанским языком владеет примерно 75-80\%.

Среди лиц моложе 50-летного возраста этот показатель колеблется в пределах 30-40 \%, тогда как среди табасаранской молодежи (до 30 лет и меньше) доля владеющих азербайджанским языком не составляет и $10 \%$. Современная табасаранская молодежь не имеет того широкого общения в азербайджаноязычной среде, которое имели их предки лет 60-70 назад. Тогда среди табасаранцев азербайджанский (тюркский) язык широко использовался в межэтническом общении, занимал прочные позиции в общественном быту. Соседство с г. Дербентом, торгово-обменные связи между азербайджанскими и табасаранскими селами и другие причины обусловили формирование в этой части Южного Дагестана азербайджано-язычной социокультурной среды. Дербент еще лет 30 тому назад оставался преимущественно азербайджаноязычным городом, а экономика Табасарана была в основном ориентирована на дербентский рынок. Кроме того, азербайджанские села занимались преимущественно зерновым хозяйством, а табасаранские - разведением технических культур и животноводством. Замечено, что в полиэтничной среде пассивность в усвоении другого языка проявляют, при прочих равных условиях, те из торговых партнеров, которые имеют зерно.

В с. Алак, Цанак, Хучни, Ерси азербайджанское население свободно говорит на табасаранском языке, а в табасаранских с. Хапиль и Татиль почти все взрослое население знает азербайджанский язык.

С появлением первых светских школ преподавание в Табасаранском районе велось на азербайджанском языке. Но уже с 1928 г. начали преподавать табасаранский язык. Сегодня в Табасаранском районе обучением табасаранскому языку охвачены все учащиеся начальных классов.

В советское время табасаранская газета читалась в каждой табасаранской семье. Ныне ее получает ограниченное количество читателей. Ежегодно уменьшается число подписчиков, но это не связано с потерей интереса к газете, а с проблемами, возникшими на почве материального благосостояния семей.

В наши дни на табасаранских свадьбах азербайджанские песни исполняются редко, хотя в музыкальном сопровождении свадьбы азербайджанская музыка и азербайджанские танцы занимают главенствующее место. Нередко в перерывах между танцами поются азербайджанские мугамы - признак высшего исполнительского мастерства певцов. Среди табасаранцев лиц, владеющих разговорным горскоеврейским (татским) языком, единицы. Однако даргинский и лезгинский языки знают многие из них. Так, жители с. Сыртич в массе своей знают, а многие и свободно владеют лезгинским языком. Жители с. Хурик и Гуртун понимают и могут изъясняться с даргинцами на бытовом уровне.

Последние годы отмечены ростом этнического самосознания народов Дагестана. Выражается это не только в повышенном внимании к вопросам представительства тех или иных народов в структурах власти, но и в возросшем интересе к проблемам сохранения и развития родных языков, в инициативах по созданию письменности на «бесписьменных языках».

Как пишет Н.Д. Сулейманов: «В 20-х годах поднимался вопрос о создании письменности на агульском языке. В постановлении ЦИК Дагестанской АССР 7-го созыва указывалось: «НКПросу и Институту Дагкультуры наметить ряд мероприятий по изучению возможности создания для мелких горских народностей (агульцы, рутульцы, дидоевцы) письменности и учебников на их родных языках. Но из-за малочисленности носителей агульского языка, как и носителей рутульского и дидойского языков, из-за отсутствия подготовленных кадров и по другим причинам этот вопрос не получил положительного решения. С 1952/53 учебного года, - пишет автор, - агульские школы с первого класса перешли на русский язык» (Сулейманов Н.Д., 1993. С. 8). 
В свое время А.И. Холмогоров факт перехода на русский язык обучения агулов, рутулов и цахуров прокомментировал так: «...эти явления свидетельствуют, что национальное самосознание отдельных народностей СССР поднялось до понимания объективной необходимости самоассимиляции...». (Холмогоров А.И., 1982. С. 66-67).

Начиная с 1992 г. обучение в агульских школах ведется на родном языке. На агульском языке выходит районная газета «Агъуларин хабарар» («Агульский вестник»). Агульский язык преподается в дербентском педучилище и Дагпединституте. «С созданием письменности на агульском языке, - отмечает Н.Д.Сулейманов, открываются широкие возможности для культурного и духовного самовыражения их носителей» (Сулейманов Н.Д., 1993.С.8). Понятно, что широта этих возможностей ограничена пределами функционирования и количеством носителей этого языка (около 20 тыс. чел., из которых примерно две трети проживает в пределах Дагестана).

Примеры, характеризующие различные формы социально-коммуникативного взаимодействия языков в рассматриваемом регионе, можно продолжить. Но из изложенного выше явствует, что специфика развития этноязыковых процессов в Дагестане вообще и в Южном Дагестане, в частности, не может быть объяснена в рамках устоявшегося с советских времен методологического клише: «расцвет языков и культур через сближение и сближение через расцвет».

В заключение отметим, что район Прикаспийской низменности от подступов к Дербенту, г. Дагестанские Огни, с. Геджух, Чинар и до с. Белижди и близлежащих к нему сел можно представить и как формирующуюся вокруг Дербента городскую агломерацию с соответствующими ей социально-экономическими компонентами и параметрами, и как единое поле динамично развивающихся этноязыковых процессов. Процессы эти далеко не завершены, хотя основной вектор их динамики, т.е. расширение социально-коммуникативных и культурных функций русского языка, представляется определенным.

\section{БИБЛИОГРАФИЯ}

Алимова Б.М., 1992. Табасаранцы. Историко-этнографическое исследование. XIX начало XX в. Махачкала.

Артамонов М.И., 1962. История хазар. Л.

Бакиханов А.-К. А. , 1926. Гюлистан-Ирам. Баку.

Буниятов 3. М. , 1965. Азербайджан в VII-IX вв. Баку.

Вагабова Ф., 1970. Формирование лезгинской национальной литературы. Махачкала.

Гаджиев A. Вопросы языка и алфавита. Правы ли тт. Гаджибеков и Минеев? (В порядке обсуждения) // Газ. «Красный Дагестан». 6 февраля 1928 г. № 30.

Гаджиев В.Г., 1965. Роль России в истории Дагестана. М.

Гаджиев М.С., 2000. Древний город Дагестана: Опыт историко-топографического и социально-экономического анализа. М.

Гадло А.В., 1979. Этническая история Северного Кавказа. IV-Х вв. Л.

Гамзатов Г.Г., 2000. Дагестанский феномен возрождения. Махачкала.

История, география и этнография Дагестана XVIII-XIX вв.: Архивные материалы. 1958 / Под ред. М.О. Косвена и Х.М. Хашаева. М.

Каймаразов Г.Ш., 1971. Очерки истории культуры народов Дагестана. М.

Козубский Е.И., 1906. История Дербента. Темир-Хан-Шура.

Минеев А. Еще раз о языке, еще раз об алфавите. Ответ В. Тарбееву // Газ. «Красный Дагестан». 13 февраля. 1928 г. № 36.

Минорский В.Ф., 1963. История Ширвана и Дербенда X-XI веков. М.

Поездка Г. Бекера по Южному Дагестану, 1876. //ССКГ. Вып. IX. Тифлис.

Сулейманов Н.Д., 1993. Сравнительно-историческое исследование диалектов агульского языка. Махачкала.

Тарбеев В. Вопросы языка и алфавита. По поводу статьи Т.Минеева (В порядке обсуждения) // Газ. «Красный Дагестан». 2 февраля. 1928 г. № 27.

Холмогоров А.И., 1982. Национальные отношения в социалистическом обществе. 
Проблемы научного управления. Киев.

Шиллинг Е., 1996. Агулы // Панек Л.Б., Шиллинг Е.М. Сборник очерков по этнографии Дагестана. Махачкала.

Шихсаидов A.P., 1975. Дагестан в X-XIV вв.: Опыт социально-экономической характеристики. Махачкала. 